\title{
Political \\ Intersectionality: \\ Tackling Inequalities in Public Policies in Scandinavia
}

By ANETTE BorCHORST AND MARI TEIGEN

Political intersectionality has mainly been addressed from a normative and a political strategic approach, whereas a theoretical and analytical focus on political intersectionality bas not been in the foreground. The intersectionality paradigm contributes with new perspectives to the study of public policies. An interesting question is, whether the intersectionality approach may stand alone, when structural aspects of inequality are in focus, or whether it is important to address different dimensions of inequality separately. Scandinavian policies provide an interesting case to raise this issue.

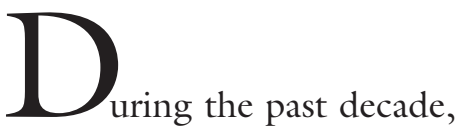

the intersectionality approach has moved centre stage in feminist thought. The key issue is how oppression, subordination and privilege cut across different systems of differentiation. It is widely accepted that the intersectionality approach is innovative in its call for systematic reflections on how structures of differentiations mutually constitute each other. To gender research it was, by and large, a new way of thinking that gender is not a priori the most central dimension to explore. The recognition that gender systematically interacts with other categories coincided, but was not entirely overlapping, with the post-structural turn in feminist thought. Today, the intersectionality paradigm is employed in a variety of disciplines, and it addresses an increasing number of issues. Within the different studies, scholars draw on previous insights and conceptualizations, but the intersectional exercise also calls for a reworking of existing concepts. 
In much of the early intersectionality literature, the consequences of multiple oppressions for identity formation were a recurrent issue. This debate was driven by an urge to challenge identity politics, and it often triggered considerations on alternative political responses to intersecting oppression. While this represents a compelling normative issue, political strategies and solutions to intersecting patterns of oppression also constitute a field that deserves to be theorized and analyzed empirically. Political intersectionality was not in the foreground during the early phase of the intersectionality debate, and macro-political intersectionality was particularly under-theorized. During recent years, an increasing number of American scholars have addressed public policies from an intersectionality perspective, whereas the European intersectionality debate so far has not been much preoccupied with this issue. ${ }^{1}$

This article addresses how multiple grounds of marginalization, oppression and privilege in relation to class, gender, and ethnicity are tackled (or not) in public policies. Our point of departure is the idea that selecting and tackling inequalities in public policies is influenced by economic, political, and discursive opportunity structures. Further, it is influenced by power structures that are decisive for who define policy goals in relation to specific groups and how this is done (Hancock 2007, Lombardo et al. 2009). We are also inspired by historical institutionalism and the idea that timing and sequence are decisive for the inclusion and exclusion of political issues at the political agenda, whereby path dependant processes fundamentally shape different policy areas (Peters et al. 2005, Ferree 2009). We find a comparative approach fruitful for analyzing these processes, because the national differences in scope, content and form of political intersectionality often serve as an eye opener for examining national responses that appear given and self evident. The empirical context of the article is Scandinavia, i.e. Denmark, Norway, and Sweden. This provides an interesting illustration of macro political intersectionality, since these countries have been characterized by state optimism. The countries have a legacy for emphasizing equality as an integral part of their political image, and it has even been claimed that they have a 'passion for equality, justice and liberty '(Graubard 1986: 7-15). Today it is questioned how far this passion reaches.

Ethnicity was not a central issue in the political debates in these countries until the late 1990s, partly because they were characterized by relatively ethnic homogeneity. With the emerging multiculturalism during the past two to three decades, ethnic differences have become politicized, and the conditions for ethnic minority groups have been placed high on the political agenda, where it remains a contested issue and a salient topic in electoral campaigns. The intersection between gender and ethnicity has turned out to be particularly controversial, and it has reshaped the political debate on gender equality.

The article proceeds in three parts. We commence by arguing for the adoption of a multi-layered approach to the study of political intersectionality. We introduce a distinction between macro, meso and micro level processes, which are characterized by different dynamics, institutions and actors. Another distinction relates to unitary, multiple and intersectional approaches. Subsequently, we address the priority ascribed to class, gender and ethnicity in the Scandinavian context. Finally, we discuss to what extent and in what manner gender equality and integration policies in the three countries have incorporated intersectional perspectives during the recent period.

MACRO, MESO AND MICRO LEVELS OF POLITICAL INTERSECTIONALITY

Kimberle Crenshaw (1991, 1993) distinguishes between structural and political in- 
tersectionality. This represents a fruitful heuristic tool to mark the differences between systems of oppression and the political strategies to tackle them. She analyzes structural intersectionality as the differentiating experiences of black and white women, whereas political intersectionality is related to feminist and antiracist political strategies. In addition to this, we find it clarifying to distinguish between macro, meso and micro processes of political intersectionality, since they are characterized by different dynamics, actors, and outcomes. We define the micro level as every day politics, the meso level as related to movements and organizations, and the macro level as national processes of policy making.

Crenshaw deals with the connection between micro level processes and macro level dynamics in an article on how American courts frame and interpret stories of black women plaintiffs in cases about employment (Crenshaw 1991). She demonstrates how black women are caught between on the one hand, the single-axis framework of antidiscrimination law and the related practices of the courts and on the other hand, existing race and gender hierarchies. Meso level processes of political intersectionality are included in terms of political strategies of black liberation politics. In another article, Crenshaw addresses the link between micro and meso level processes. She analyzes the problems black women face when the intersecting dynamics of their race, class, and gender are not considered together in cases of battering of women (Crenshaw 1993). According to her, the political strategies of feminist and antiracist movements frequently reproduce the subordination of black women.

Ange-Marie Hancock's distinction between unitary, multiple and intersectional approaches is a fruitful heuristic tool for understanding what characterizes intersectionality. A unitary approach implies that one single category is regarded as the only or the most relevant category as point of departure. A multiple approach recognizes several categories and treats them as equally important and autonomous. An intersectional approach deals with many categories and underscores the interaction between them. Hancock concludes that the two first approaches tend to treat the various categories as static, and she strongly advocates for an intersectional approach (Hancock 2007). We find that studies of intersectionality are not necessarily and by themselves more dynamic than unitary and multiple approaches, partly due to the very high complexity involved in analyzing the interactions between many categories. We agree with scholars who argue that unitary and multiple approaches for analysing identity formation are truly problematic, since individuals are not able to separate their gender from their ethnic background, class, etc. It is also problematic to attribute a common subjective identity to women as a gender, because it cements gender as a point of departure for identity formation. Yet, as Young argues in her defence of the category of gender, there is a clear difference between micro level identity formation and macro level structural oppression, where for instance gender is a relevant category to study (Young 2002). She concludes that there are three aspects of gendered structures: the first is the division of labour and the public-private split; the second relates to sexuality and hetero-normativity, and the third is gendered power hierarchies. It is debatable, whether these gender structures operate independently of time and space, but in so far as general patterns of gendered oppression are identifiable at a structural level, it points in the direction of treating them as autonomous system of oppression. As Laurel Weldon argues, the very idea of intersectionality assumes that social structures are determined by social positions (Weldon 2008). These systems may have autonomous effects at the same time as they intersect. On this background, she concludes that an intersectional ap- 
proach cannot stand alone as an analytical strategy. Hence, this is an argument for the relevance of analyzing structural patterns of inequality in terms of class, gender, and ethnicity in a multiple way, i.e. as isolated phenomena, as well as from an intersectional perspective, which is imperative for understanding the complexity of political power and the interwoven patterns of inequality.

The question is, whether one could make the same argument about public policies that address inequalities. If Young and Weldon are right, gendered structures operate autonomously (and the same is true of class and ethnicity), this could justify the existence of public policies addressing one dimension in particular (like gender equality policies). However, since policy goals are often determined according to who has the power to influence the political agenda it may also be the case that policies that are framed in relation to one dimension, like gender equality, may take its point of departure in the living conditions of specific groups.

At the same time, an intersectional perspective in public policies may target specific groups and frame their needs on the basis of stereotypes about their culture. This illustrates that an intersectional perspective may not necessarily turn out to be more inclusive in terms of acknowledging the specific needs and structural patterns of inequality related to these groups, and it may instead turn out to be exclusive (see also Christensen and Siim's article in this issue). In the following we will pursue these questions about which priorities have been ascribed to specific dimensions of inequality in public policies in Scandinavia, and whether the policy logic of these policies has been unitary, multiple or intersectional.
CLASS, GENDER, AND ETHNICITY IN THE SCANDINAVIAN CONTEXT

The inclusion and exclusion of issues on the political agenda is shaped by the capacity of specific groups of citizens to form viable alliances to generate political attention to their claims and the power to shape the political discourse in favour of their needs. Furthermore, the priority ascribed to inequalities connected to class, gender and ethnicity has been influenced by path dependant processes. This implies that economic, political and discursive opportunity structures and the strength of political actors at formative moments of public policies, are decisive for how different inequalities are framed and tackled in different countries. Different dimensions of differentiation have been subject to shifting political priorities in different countries.

In Scandinavia, the first half of the $20^{\text {th }}$ century saw the development of social or welfare policies that above all framed class inequality as the primary concern, because the peasant movement and the labour movement successfully shaped the political agenda in the formative years of the welfare state. In this way, the policies mainly had a unitary character. The emphasis on class policies has been ascribed to the dominance of social democracy, but many decisions were consensual or passed by coalitions of several political parties. An important precondition for the consensual policy processes was the institutionalization of the class conflict in corporatist structures that provided the social partners with a wide room to manoeuvre and regulate the labour market through collective agreements. They also obtained considerable influence on the political agenda and a wide range of political decisions, particularly from the 1960s and some decades onwards. The Scandinavian welfare states were characterized by relatively generous policies of economic redistribution and a high degree of decommodification, i.e. the extent to which welfare benefits make 
labour independent of market forces (Esping-Andersen 1990). The countries are still today characterized by relatively low income differences.

Gender equality also played a certain role in policy making during the first part of the $20^{\text {th }}$ century in Scandinavia, and the framing of women's demands by the women's organizations were successful in generating political reforms for women (Bergqvist et al. 1999: 297). Still, gender issues were often framed as private or family matters and excluded or downgraded at the political agenda. This was even more pronounced in the collective agreements, which have been the primary regulation of the labour market in Scandinavia. One reason for this was the strong position of the social partners (Skjeie and Teigen 2003, Borchorst forthcoming).

During the 1970's, all three countries established gender equality policies with a separate policy machinery, but the countries were characterized by very different opportunity structures during this formative period of the policies. The Danish polices were established during a period of unfavourable economic, political and discursive opportunity structures, compared to the two other countries (Borchorst 2004). Therefore, the Danish policies are characterized by weaker institutions and fewer active measures. Norwegian gender equality policies have emphasized active measures and in particular quotas and positive action to promote a gender balance within working life, business and politics (Skjeie and Teigen 2003). Sweden is characterized by extensive gender equality policies, consisting of active and binding measures, however to a lesser extent than in Norway.

Ethnicity appeared relatively late on the political agenda in all three countries, among other things due to the relatively high degree of homogeneity of the populations. Furthermore, since it appeared in the 1980s it has become subject to a very high degree of politicisation and unfavourable political and discursive opportunity structures. Policies related to ethnic minorities have been less preoccupied with inequalities and discrimination than welfare policies and gender equality policies during their formative periods. There are, however distinct differences between the three countries. The relation between immigration and the welfare state in the three countries have been characterized as the liberal Sweden, the restrictionist Denmark, and Norway somewhere in the middle (Brochmann and Hagelund 2010). Although, as noted by Hedetoft, integration policies in Sweden and Denmark converge at the practical level and diverge discursively (Hedetoft 2006: 401).

Hence, by and large, the general policy approach in Scandinavia has been to address different groups and dimensions separately in welfare policies, gender equality policies and immigration policies. Seen in an overall perspective across the different policies, this implies that policy logics have been multiple. The question remains whether a unitary logic of, for instance, gender policies addresses structural perspectives of gender inequality that is common for women (or men) of all classes and ethnic groups, or whether they have for instance been modelled around the lives of white middle class women.

\section{GENDER EQUALITY POLICES AND INTEGRATION POLICIES: UNITARY OR INTERSECTIONAL?}

In the following, we analyze the changes in gender equality and integration policies in the Scandinavian countries in later years. We further discuss, whether their policy logics have been unitary or intersectional and if so, if they are based on stereotypes about particular groups and tend to be exclusive or if it is framed in an inclusive way. 


\section{GENDER EQUALITY POLICIES}

Gender equality, as a focused policy concern with separate machinery, was introduced in the 1970s as a policy logic that targeted gender, or rather women, and their inequality. Relatively modest focus was ascribed to class and ethnicity, since it was not regarded as a relevant dimension during this period. The policies were above all influenced by the mobilization of women that managed to generate responses from the state in terms of public policies focusing on women and gender. Gender equality was mainly framed as a matter of integrating women in paid work, particularly in Sweden and Denmark.

During the past decade, the unitary paradigm of gender equality policies has been challenged and the diversities of men and women, especially in regard to ethnicity, receive increased attention. This applies especially to Denmark, where gender equality among ethnic minorities has become a recurrent issue (Langvasbråten 2008, Borchorst and Siim 2008). In Norway and Sweden, a unitary gender perspective is the main approach, and intersections of gender and ethnicity in policy-making are less part of the general political discourse of problems of gender equality (Langvasbråten 2008: 39). In Norway a 'crisis frame' of gender equality has increasingly emerged, under influence of the Danish debate, with a particular emphasis on forced marriages and female genital mutilation (Langvasbråten 2008, Teigen and Langvasbråten 2009). However, in Norway, these issues are not included in mainstream gender equality policy.

The gender equality policy of Danish governments since 2001 has above all targeted ethnic minority women, which are claimed not to enjoy gender equality to the same extent as the majority group (Borchorst and Siim 2008). Hence, there has been a clear development from a unitary towards an intersectional policy logic, although the ethnic minority women are framed as a weak group that suffers from their own culture. Structural aspects of gender equality have been downplayed for both minority and majority women. Furthermore, gender differentiations related to class are downplayed. The Danish gender equality policies are accordingly framed in an exclusive way in relation to minority women. The tendency to directly and solely address gender equality in relation to ethnic minorities in Danish gender equality policies do, however, not apply to all issues. The lack of women in management, science and political decision-making, are approached in a unitary perspective. This tendency to apply an explicit intersectional approach to some policies while others remain within the unitary paradigm, appear to support the post-colonial criticism that asserts that Scandinavian gender equality policies have a tendency to disregard the differentiated character of gender relations, which in consequence has led to a privileging of white, heterosexual, middleclass women (de los Reyes and Mulinari 2005: 79, Mulinari et al. 2009: 3).

\section{INTEGRATION POLICIES}

Integration policies in all three countries have mainly been characterized by a unitary logic targeting ethnic minorities, or more precisely non-western immigrants and their descendants. Gender has sometimes been framed as a relevant focus, but less incorporated in forms of gender sensitive integration policy measures. Class is not explicitly considered, although the emphasis on policies to promote education attainments and labour market inclusion interconnects with class related issues of social and economic redistribution. In this sense, integration policies have become a 'new' policy field of redistributive policies, with its strong emphasis on marginalisation, inclusion into employment, and economic deprivation among ethnic minorities. In spite of this, the actual policy-making and the solutions 
proposed appear mainly to treat the ethnic minority population as a unitary and undifferentiated group. The adoption of the Danish starting-out assistance for refugees based on a level of social benefits that are much less generous than the ordinary social assistance level, and the 300 hours rule that restrict the access of couples to social benefits $^{2}$ (Hansen 2006) constitute a break with the universal and individual character of Danish redistributive policies.

In the last couple of decades the debate on immigration, integration, gender, and family relations has been a growing field in the public discourse. Especially in Denmark and Norway family relations of ethnic minorities have been increasingly questioned, and multiculturalism has been placed in direct opposition to core values of welfare, individual freedom and gender equality (Hagelund 2008). Typically, there exist vagueness in regard to the underlying political motives and whether the aim primarily is to enhance integration, reduce immigration as well as to fuel immigration hostility within the majority population.

In Denmark, integration policies have focused on forced marriages and low employment rates of women. In Norway, forced marriages and female genital mutilation have been central issues, and in Sweden honour related violence has been in focus. Yet, in Sweden this is not addressed as a specific ethnic minority issue, but rather as an example of the universal gender based power structure (Langvasbråten 2008: 46).

These policies have been labelled a new 'crisis' oriented political agenda, where the minority population becomes a target group that lacks gender equality (Siim and Skjeie 2008: 323). Xenophobic and right wing parties that have generally been reluctant to support political initiatives of gender equality for the majority population today praise gender equality as core welfare state values, dividing the ethnic majority from the minority (Akkerman and Hagelund 2007).
This tendency to make a crude divide between minority and majority illustrates the ways in which intersectional approaches are not necessarily inclusive, but can operate exclusionary and by this reinforce the stereotyping of specific groups (see also Christensen and Siim's article in this issue).

\section{CONCLUDING REMARKS}

Intersectionality has become tremendously popular in many disciplines of feminist thought, and it is fruitful to adopt a multi level approach to this concept, distinguishing between macro, meso and micro level processes of differentiation. These levels interact, but they are also characterized by different dynamics, actors and outcomes. We focus on political intersectionality, which so far has been addressed mainly at a micro level of every day politics and as meso level processes related to the strategies of movements and organization. A macro level of public policies has been approached by an increasing number of American scholars, but it has not been in the foreground of the European debate.

We engage in the debate on whether an intersectional approach can stand alone analytically in terms of understanding mechanisms of inequalities related to class, gender and ethnicity, or whether it may be important to supplement the intersectionality perspective with a focus on one dimension at a time, as Irish Yong argues in her defence of gender as a relevant category. This issue is also relevant for public policies, and we question whether the concept of intersectionality is sufficient to capture the challenges of policymaking in an increasingly diversified society. Furthermore, we discuss whether intersectionality is framed in an inclusive way or on the basis of stereotypes of specific groups that has an exclusive character.

The conclusion is that the Scandinavian countries in the first half of the $20^{\text {th }}$ century adopted welfare policies that were, above 
all, framed to reduce class inequalities. Policies of gender equality were established during the 1970's onwards, whereas policies of integration have been introduced to the political agenda during the past decade. Hence, a multiple policy logic behind the establishment of these policies has developed in subsequent steps emphasizing at first class inequality, and next gender inequality. Finally, ethnicity has been placed on the political agenda, but with much less emphasis on inequality compared to class and gender. The priority ascribed to the different dimensions in public policy making and issues of inequality and discrimination has been shaped by the economic, political, and discursive opportunity structures during the formative moments of these policies. The political mobilization and empowerment of the working class, women and ethnic minority groups at these formative moments have also been significant for the policy logics.

The analysis of policies of gender equality and of integrations policy indicates that they have had a strong unitary logic. It is in the interconnections between integration and gender equality policies that tendencies of intersectional approaches most typically emerge. This is most evident in Danish policymaking, less in Swedish, while Norway can be placed somewhere in the middle. Intersectional approaches to gender and ethnicity emerge in mainstream Danish gender equality policy. While the official claim in Denmark is that gender equality is already achieved, it is framed as a serious problem for ethnic minority women. In addition, central aspects of integration policies, especially the parts that interconnect integration and migration policies, are characterized by intersectional approaches of gender and ethnicity. This applies in particular to Danish and Norwegian policies and issues such as forced marriages, female genital mutilation etc.

Bridging intersectionality with theoretical reflections on policy approaches to class, gender and ethnicity offers an opportunity to raise new issues in policy analysis as well as in intersectionality studies. Intersectionality does not in itself necessarily contribute to a more dynamic approach than unitary and multiple approaches, partly because of a very high complexity involved in analyzing the interactions among many categories. It is of course relevant to criticize unitary approaches if they ignore difference of relevance for structures of redistribution, recognition and participation. We have, however, demonstrated that intersectionality may be applied in a very exclusive way, most notably in Denmark, where ethnic minority women are targeted as a group that do not enjoy the gender equality that majority women have achieved. Intersectional approaches may, accordingly, cultivate and exaggerate differences between majority and minority, leading to the targeting and stereotyping of ethnic minority women/girls (and to some extent minority boys/men). This is especially true of Danish gender equality policy and particular aspects of Danish and Norwegian integration policies. Thus, neither intersectionality nor unitary approaches can stand alone.

\section{NOTES}

1. In Europe, there has been an increasing interest in institutional intersectionality. This development was triggered by the adoption of article 13 in EU's Treaty of Amsterdam, which prohibits discrimination according to six strands: sex, racial and ethnic origin, disability, age, religion, and sexual orientation and by the recommendation to set up judicial institutions to deal with cases of multiple discrimination (Verloo 2006, Squires 2009). This development has involved an increasing preoccupation with how transnational and national political processes of intersectionality interact. This is highly relevant due to the changing role of nation states, increasing migration and the role of international organizations in the advocacy of protecting human rights. 
2. The rule applies to all citizens, but it is aimed at immigrants, and it hits them much harder than the ethnic majority population.

\section{LITERATURE}

- Akkerman, Tjitske and Anniken Hagelund (2007): "Women and Children first! Anti Immigration parties and gender in Norway and the Netherlands", in: Patterns of Prejudice 41, 2. - Bergqvist, Christina et al. (red.) (1999): Equal Democracies? Gender and Politics in the Nordic Countries. Scandinavian University Press, Council of Nordic Ministers, Oslo.

- Borchorst, Anette (2004): "Skandinavisk ligestillingspolitik tur-retur, på dansk billet”, in: Nytt Norsk Tidsskrift/3-4.

- Borchorst, Anette (forthcoming): "Ligeløn, institutionelle spilleregler og kollektive aktører", in: Mette Deding, Helle Holt, Lisbeth Pedersen (eds.): Ligeløn, Socialforskningsinstituttet, København.

- Borchorst, Anette and Birte Siim (2008):

"Woman-friendly Policies and State Feminism: Theorizing Scandinavian Gender Equality", in: Feminist Theory/9, 26.

- Borchorst, Anette and Mari Teigen (2009): Who is at issue - what is at stake? Intersectionality in Danish and Norwegian gender equality policies. Paper presented at ECPR Joint Session of Workshops, Lisbon, 14-19 April.

- Brochmann, Grete and Anniken Hagelund (2010): Velferdens grenser, Universitetsforlaget, Oslo.

- Crenshaw, Kimberle (1991): "Demarginalizing the Intersection of Race and Sex: A Black Feminist Critique of Antidiscrimination Doctrine, Feminist Theory, and Antiracist Politics", in: Katharine T. Bartlett and Rosanne Kennedy (eds.): Feminist legal theory. Westview, Boulder, CO.

- Crenshaw, Kimberle (1993): "Mapping the Margins: Intersectionality, Identity Politics, and Violence Against Women of Color", in: Stanford Law Review/6.

- de los Reyes, Paulina \& Diana Mulinari (2005):

Intersektionalitet. Liber, Malmö.

- Esping-Andersen, Gøsta (1990): The Three

Worlds of Welfare Capitalism. Polity Press, Oxford. - Ferree, Myra Marx (2009): "Inequality, intersectionality and the politics of discourse: framing feminist alliances", in: Emanuela Lombardo, Petra Meier and Mike Verloo (eds.): The discursive Poli- tics of Gender Equality, Routledge/ECPR Studies in European Political Science, Oxon.

- Graubard, S. (ed.) (1986): Norden: The Passion for Equality. Norwegian University Press, Oslo. - Hagelund, Anniken (2008): For women and children! The family and integration politics in Scandinavia. IMISCOE Research Series. Amsterdam: Amsterdam University Press.

. Hancock, Ange-Marie (2007): "When Multiplication Doesn't Equal Quick Addition: Examining Intersectionality as a Research Paradigm", in: Perspectives on Politics/5, 1 .

- Hansen, Hans (2006): From Asylum Seeker to Refugee to Family Reunification. Study No. 13, The Rockwool Foundation Unit and Statistics Denmark, Copenhagen.

- Hedetoft, Ulf (2006): "Divergens eller konvergens? Perspektiver i den dansk-svenske sammenstilling", in: UIf Hedetoft, Bo Petersson and Lina Sturfelt (eds.): Invandrare och integration i Danmark och Sverige, Halmstad: Makadam Förlag \& Centrum för Danmarksstudier.

- Langvasbråten, Trude (2008): “A Scandiavian Model? Gender Equality Discourses on Multiculturalism", in: Social Politics/15, 1.

- Lombardo, Emanuela, Petra Meier and Mike Verloo (eds.) (2009): The discursive Politics of Gender Equality. Routledge/ECPR Studies in European Political Science.

- Mulinari, Diana, Suvi Keskinen, Sari Irni and Salla Tuori (2009): "Introduction: Postcolonialism and the Nordic Models of Welfare and Gender", in: Suvi Keskinen, Salla Tuori, Sari Irni and Diana Mulinari (eds.): Complying With Colonialism. Ashgate.

- Peters, Guy B., Jon Pierre and Desmond King (2005): "The Politics of Path Dependency: Political Conflict in Historical Institutionalism", in: The Journal of Politics/67, 4 .

- Siim, Birte and Hege Skjeie (2008): "Tracks, intersections and dead ends: Multicultural challenges to state feminism in Denmark and Norway", in: Ethnicities/8, 3.

- Skjeie, Hege og Mari Teigen (2003): Menn imellom. Gyldendal forlag, Oslo.

- Squires, Judith (2009): Intersecting Inequalities: Britain's Equality Review. Paper given at the First ECPR Conference on Politics and Gender, Belfast 21.-23. January.

- Teigen, Mari and Trude Langvasbråten (2009): "The "Crisis" of Gender Equality: The Norwegian Newspaper Debate on Female Genital Cutting", in: NORA - Nordic Journal of Feminist and Gender Research/17, 4.

· Verloo, Mieke (2006): Multiple Inequalities, 
Intersectionality and the European Union, European Journal of Women's Studies 13, 3.

- Weldon, Laurel, S. (2008): Intersectionality, in: Gary Goertz and Amy G. Mazur (eds.): Politics, Gender and Concepts. Theory and Methodology. Cambridge University Press, Cambridge.

. Young, Iris Marion (2002): "Lived body vs. gender: reflections on social structure and subjectivity", in: Ratio/XV 4 December.

\section{SUMMARY}

Political Intersectionality: Tackling Inequalities in Public Policies in Scandinavia An analytical approach to political intersectionality has not been in the foreground of the intersectionality paradigm during its first phase. It may, however, generate new insights, both for the intersectionality tradition and for the study of policies that are aimed at influencing social differentiations. The article explores the theoretical background of political intersectionality with a focus on public policies, which relates to a macro level of political intersectionality. A central issue is whether policies are based on a unitary, a multiple or an intersectional policy logic. Moreover, the questions are whether and intersectional approach is inclusive or if it exclusively can stand alone, and, further, whether it is always positive. This is addressed empirically in relation to gender and integrations policies in the three Scandinavian countries.

Anette Borchorst, Professor Department of History, International and Social Studies

Aalborg University

Mari Teigen, Dr. polit.

Research Director

Institute for Social Research, Norway 